\title{
Erratum to: Collaborative Partnerships and the Future of Global Orthopaedics
}

\author{
Saam Morshed MD, PhD, MPH, David W. Shearer MD, MPH, \\ R. Richard Coughlin MD, MSc
}

Published online: 9 November 2013

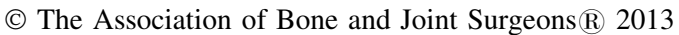

\section{Erratum to: Clin Orthop Relat Res (2013) 471:3088-3092 DOI 10.1007/s11999-013-3145-x}

The Orthopaedic Healthcare Worldwide column entitled, Collaborative Partnerships and the Future of Global Orthopaedics (DOI 10.1007/s11999-013-3145-x) should have had the Column Editor's Note at the beginning of the column in its entirety. The note said:

A Note From the Column Editor: The practice of medicine is no longer constrained by geographical borders. Innovative technologies have dramatically improved our ability to share ideas and learn from colleagues from around the world. Although North American surgeons have increasingly demonstrated a willingness to share their time, expertise, and knowledge with healthcare providers from resource-poor countries through surgical and educational missions, we also have much to learn from our colleagues in the developing world regarding strategies and tactics for preventing and treating musculoskeletal disease with limited resources. This type of knowledge transfer will become increasingly important as our own healthcare system is challenged to do more with less. In this article, Morshed et al. describe the current state of interaction between surgeons across the globe, and provide a roadmap for future collaboration that will enhance all of our abilities to improve the value of care we provide for our patients.

- Kevin J. Bozic MD, MBA

The editors regret this error.

The online version of the original article can be found under doi:10.1007/s11999-013-3145-x.

S. Morshed ( $₫)$, D. W. Shearer, R. R. Coughlin Department of Orthopaedic Surgery, University of California, San Francisco, 500 Parnassus Avenue MU320W, San Francisco, CA 94143, USA

e-mail: Morsheds@orthosurg.ucsf.edu 